\title{
Legal Protection for Domestic Workers: The Case of Wolaita Sodo Town, Ethiopia
}

\author{
Yared Kefyalew Demarso*, Bogale Anja Abba \\ School of Law, Wolaita Sodo University, Sodo, Ethiopia \\ Email: *yaredoo2@gmail.com, bogawassa@gmail.com
}

How to cite this paper: Demarso, Y. K., \& Abba, B. A. (2020). Legal Protection for Domestic Workers: The Case of Wolaita Sodo Town, Ethiopia. Beijing Law Review, 11, 770-781.

https://doi.org/10.4236/blr.2020.113047

Received: June 24, 2020

Accepted: September 20, 2020

Published: September 23, 2020

Copyright $\odot 2020$ by author(s) and Scientific Research Publishing Inc. This work is licensed under the Creative Commons Attribution International License (CC BY 4.0).

http://creativecommons.org/licenses/by/4.0/ (c) (i) Open Access

\begin{abstract}
This research examines legal protection for domestic workers, who are highly exposed to varieties of abuses and violence by taking the comparative analysis of some African countries like Kenya and South Africa. The best experience of these countries was selected as they extended labour law protection for domestic workers too. The International Labour Organization (ILO) has adopted the convention for special legal protection of domestic workers. Some countries of the world also signed and ratified the convention. However, Ethiopia was also signed but not yet ratified the convention and explicitly excluded domestic workers from labour law protection. The main objective of the research is to assess the legal protection of domestic workers in the study area. This research has employed doctrinal legal research and some empirical considerations were analyzed qualitatively through narration and thematic analysis techniques to articulate legal protection of domestic workers. The finding of the research indicated that there is no clear contractual agreement between employers and domestic workers, unlimited work time without rest including night time, work with less or no remuneration, abuses and sexual violations. The research also revealed that there is violation of rights of the domestic workers due to multiple factors but the legal protection is inadequate. Some of those factors include bargaining power imbalance, lack of clearly agreed terms of contract, illiteracy and working in private household, lack of awareness and weak realization of laws and failures of the organs of government. So, the research suggests that domestic workers need recognition and adequate legal protection due to their special vulnerability.
\end{abstract}

\section{Keywords}

Labour Law, Domestic Workers, Employment Contract, Employer, Legal Protection 


\section{Introduction}

Domestic workers are one of the most vulnerable groups in the world, being often the targets of physical and sexual abuse and experiencing discrimination and marginalization with regard to pay, working conditions and legal rights (Mulugeta, 2012). Despite their vulnerability, domestic workers continue to be one of the least protected groups of workers under domestic labour law according to the ILO data (ILO, 2013). Their vulnerability to abuses, harassment and violence is due to the relationship of submission, paternalistic view, low economic status, low level of education, nature of the work and isolation (Gebremedhin, 2016). Lack of recognitions as workers and inadequate legal protection of their rights further exacerbate their exposure to abuse and violence (Mulugeta, 2012). Even the domestic work is not recognized as a work, ignored and undervalued $(\mathrm{Mu}-$ lugeta, 2012). It is invisible work and workers are not being recognized or respected; there is lack of law enforcement and workers are not organized (International Trade Union Confederation, 2010).

Domestic workers may engage in various types of activities. They may cook or clean, or care for children, the elderly or the disabled, with tasks that have been traditionally assigned to women in the vast majority of the societies and that have been uncompensated (ILO, 2012). However, domestic work may not be limited to these activities and it also includes gardening, chauffeuring or providing security services, tasks more often performed by men (ILO, 2012).

Domestic work is one of the oldest and most important occupations for millions of women in the world (Mulugeta, 2012). Domestic work covers up to ten percent of total employment in some countries (Mulugeta, 2012). In Ethiopia, there are also highest percentages of women among domestic workers with 91\% of which are exposed to varieties of abuses (ILO, 2013). It is rooted in the global history of slavery, colonialism and other forms of servitude (ILO, 2012). The labour rights movement of the industrial revolution demanded an end to inhuman working conditions that treated workers as mere commodity (Berlanstein, 1992). The success of the movement, though very slow and limited, became a model for other oppressed groups (Berlanstein, 1992). Women, black people, persons with disabilities, immigrant workers, and minority groups followed similar paths and have succeeded in gaining various labour rights (Berlanstein, 1992). However, a segment of the labour force remains hidden in private homes since all the movements have been concerned with public sphere labour relations (Berlanstein, 1992).

Accordingly, domestic workers are especially vulnerable groups due to various factors. There is deep power imbalance between employers and domestic workers, which makes it extremely difficult for a worker to negotiate fair working conditions, claim their rights, or refuse an employer's request (Human Rights Watch, 2018). Domestic workers need legal protection just as any other wage earner and enjoy fundamental rights (International Trade Union Confederation, 2010). So, their vulnerability necessitated special legal protection. That is why 
the ILO has extended labour rights to domestic workers after successive campaigns of various groups; particularly domestic workers organizations throughout the globe with the adoption of ILO's Convention No. 189 on Decent Work for Domestic Workers and the accompanying Recommendation No. 201 in 2011.

Under the convention, domestic workers are entitled to the same basic rights as those available to other workers in their country, including weekly days off, limits to hours of work, minimum wage coverage, overtime payment, social security, and clear information on the terms and conditions of employment. The convention is a key means by which to ensure that national legislation protects domestic workers (International Trade Union Confederation, 2010). The new standards also obliges governments that ratify the convention to protect domestic workers from violence and abuse, to regulate private employment agencies that recruit and employ domestic workers, and to prevent child labour in domestic work. In view of that, some countries of the world have provided separate laws or chapters in the labour laws and still some others have ratified the ILO Convention to protect the rights of domestic workers.

Ethiopia is a member state of the ILO and United Nations (UN) and also signatory to ILO's Convention No. 189 on Decent Work for Domestic Workers. The country, however, has not yet ratified the convention by its law making organs. According to the FDRE Constitution, for an international agreement to be an integral part of the law of the land and effective, it should be ratified by the law makers (FDRE Constitution Article 9(4), 1995). So, the ILO Convention for domestic workers needs to be ratified by the law making organ to be effective and binding in the country. Besides these, in Ethiopia, domestic workers are excluded from labour rights protection leaving them no legal rights to limits on their hours of work, a minimum wage, or adequate rest and overtime payment and etc. Therefore, domestic workers are expressly excluded from the application of the current Ethiopian Labour Proclamation No. 1156/2019 article 3(2) (d) (Here in after called "the proclamation").

The working condition, the nature of work and the associated risks that affect physical, intellectual, emotional and social development of the domestic workers is open for intensive studies. Various government and non-government actors have tried to document the prevalence and magnitude of domestic workers in Ethiopia. There are some related literatures conducted by other researchers on the issue. However, there is no research work which addresses the legal protection of domestic workers in the study area. Furthermore, there are various reasons for selection of the study area. Some of the reasons related to high numbers of domestic workers which are exposed to abuses and violations; lack of similar research conducted in the study area on the issue; accessibility and feasibility of the study area for collecting data based on the preliminary data collected by the researchers.

In addition to these, the experiences of Kenya and South Africa as these countries were extended labour rights for domestic workers too. This is with a view to 
take the best experience of those selected African countries. The main objective of the research is to investigate legal protection of domestic workers and to suggest recommendations based on the findings of the research. The findings and recommendations extend to the entire country as there is no law enacted for the protection of domestic workers in the country wide. Since domestic workers are expressly excluded from the labour law protection, the extension of labour rights to the whole labour force is an unfinished process in Ethiopia. The scope of the research is only limited to assessing the rights and privileges of domestic workers in the study area. Some of the limitations of the research include scarcity of related literatures and financial constraints which affected in depth analysis of the research.

\section{Literature Review}

The ILO Convention of No. 189 under Article 1 defines "Domestic Work" as work performed in or for a household, and a "Domestic Worker" as any person performing domestic works in the employment relationship. Nonetheless, a person who performs domestic work only occasionally or sporadically and not on occupational basis are excluded from scope of the convention (ILO Convention No. 189 Article 1(b), 2011). A domestic worker may work on full time or part-time basis; may be employed by a single household or by multiple employers; may be residing in the household of the employer (live-in worker) or may be living in his or her own residence (live-out). The convention includes both civil rights, like working time and minimum wage, taking an integrated approach towards human rights law (ILO Convention No. 189 Article 1(c), 2011). The employer of a domestic worker may be a member of the household, for which the work is performed, or an agency or enterprise that employs domestic workers and makes them available to households (ILO Convention, 2011). Generally, the labour law regulates the entire relationship between the employer and the employee (Azzam, 2019).

There is no uniform application regarding legal protection of domestic workers in the world. Some countries such as Argentina, Austria, Brazil, Burkina Faso, Central African Republic, Denmark, Finland, Hungary, Italy, Malta, Peru, Portugal, Spain, South Africa, Swaziland, Sweden, Tanzania, and Zimbabwe have enacted specific laws or regulations governing domestic work (Human Rights Watch, 2012). On the other hand some countries like Mexico, Malaysia, Paraguay, Philippines, Belgium, Bolivia, Canada (Ontario), Chile, Costa Rica, Dominican Republic, Ecuador, El Salvador, Guatemala, Haiti, Honduras, Nicaragua, Panama, and Venezuela have devoted specific chapters, titles and sections in labour codes, employment acts or acts respecting contracts of employment (Human Rights Watch, 2012). Still some other countries such as Italy, Bolivia, Paraguay, Philippines, Uruguay, Nicaragua and Mauritius have ratified the Domestic Workers Convention of the ILO (Human Rights Watch, 2012).

According to the FDRE Constitution of Ethiopia, which is the supreme law of 
the land, workers have the right to reasonable limitation of working hours, to rest, to leisure, to periodic leaves with pay, to remuneration for public holidays as well as healthy and safe work environment (FDRE Constitution Article 42(2), 1995). Based on these constitutionally guaranteed rights, other workers have provided with special legal protection by the Labour Proclamation of the country. Unlike other workers, domestic workers are not provided with the legal protection. So, domestic workers are expressly excluded from the scope of application of labour law (Labour Proclamation 1156 Article 3(2) (d), 2019).

On the other hand, the 1960 Civil Code of Ethiopia has employed the term “Domestic Servant" in order to refer "Domestic Workers" (Civil Code Article 2601, 1960). However, the code does not clearly define what domestic work is and who domestic servants are (Gebremedhin, 2016). Such a designation may be influenced by the national and international socio-political realities of the 1960s (Gebremedhin, 2016). Its implication may relate to unfavorable conditions and treatments a servant traditionally faced in the context of a master-servant relationship which involved inferior levels of treatment and protection than provided to other groups of workers (Gebremedhin, 2016).

\section{Legal Protection for Domestic Workers}

\subsection{The ILO Experience}

In general, workers are exposed to various types of abuses and violations and hence they need legal protection. Particularly, domestic workers are more vulnerable to violation of rights and abuses even as compared to other workers. Consequently, the ILO has adopted the Convention No. 189 on Decent Work for Domestic Workers and the accompanying Recommendation No. 201 in June 2011. The Convention is an attempt to provide framework for governments to give the domestic workers a decent work, one of the human rights particularly promoted by ILO (Mulugeta, 2012). Countries of the world are advised to adopt the convention as it provides minimum legal protection for domestic workers taking their vulnerability into account. The adoption of the convention on domestic workers would mean the recognition of domestic work as "work" worldwide (International Trade Union Confederation, 2010).

1) Formation of Contract: Contractual agreements determine the rights and duties of parties and bind them. The terms and conditions of contract must be specified clearly. According to article 7 of the ILO Convention No. 189 mandatorily requires establishment of formal and clear contractual agreement (ILO Convention No. 189 Article 7, 2011). So, there should be formal written contract between domestic worker and the employer. This in turn helps to protect the rights of the parties.

2) Working Hours and Rest: Working hours are those periods in a day or in a week when the employee regularly renders service to the benefit of his/her employer (Redae, 2009). The general principle is that the employers cannot require employees to work for more than eight hours per day and forty hours per week 
(Azzam, 2019). The employment contract should limit the working hours of workers pursuant to article 10 of the ILO Convention of domestic workers. Thus, workers are mandatorily required to do works for such limited time. In addition to working hours, rest time of workers must be included in the employment contract. Sub article 2 also states that the weekly rest shall be at least 24 consecutive hours. Like any other workers domestic workers also need payment for overtime work.

3) Minimum Age for Employment of Children: The minimum age for the children to conclude employment contract and involve in domestic work must be fixed by the law. Many domestic workers are children under age of 18 years, some as young as five years old (Asia Pacific Forum on Women, 2010). According to the ILO estimated that more girls under sixteen work in domestic service than in any other category of child labour (Asia Pacific Forum on Women, 2010). Child domestic workers are vulnerable to sexual harassment abuse in household (Asia Pacific Forum on Women, 2010). The minimum age in labour law is determined with 14 years (Azzam, 2019). Child labour should be abolished in order to protect them from economic exploitation and work that would interfere with their education, health and development (Gebremedhin, 2016).

4) Remuneration: The service should not be a pro bono service and the domestic workers must be entitled to payment for the service they provided. According to article 11 and 12 of the ILO Convention states the obligation to provide minimum wage coverage for domestic workers and they should be paid monthly remuneration directly in cash at regular interval (ILO Convention No. 189 Articles 11 and 12, 2011).

5) Working Environment: Domestic workers have the right to safe and healthy working environment. They should be protected from verbal and physical abuses and sexual violence. Verbal abuse may include nagging and use of derogatory labels, jokes on domestic workers and their mistakes (Mulugeta, 2012). The most common forms of physical abuse are slapping, being spat on, and being kicked by foot or having nearby objects thrown at them (Mulugeta, 2012). Sexual violence ranged from unwanted body contact to rape (Mulugeta, 2012). The employer is obliged to prepare favorable working environment. Article 13 of the ILO Convention has recognized that domestic workers right to safe and healthy working environment (ILO Convention No. 189 Article 13, 2011).

6) Freedom of Association: Domestic workers should be entitled to form association and organized. The Convention under article 3(3) requires member states to ensure that domestic workers enjoy freedom of association and the right to collective bargaining (ILO Convention No. 189 Article 3(3), 2011). The right to freedom of association of employees also recognized by Freedom of Association and Protection of the right to organize Convention No. 87 of 1948 and Right to Organize and Collective Bargaining Convention No. 98 of 1949.

7) Conditions of Termination of Employment Relationship: Since employment contract is type of a contract it can be terminated/extinguished/due to var- 
ious reasons. There are also various ways by which labour contract can be extinguished. The labour laws are enacted to preserve the employees from arbitrary decisions of the employers and to secure employment security of the former. The conditions of termination of employment contract and compensation upon termination should be clearly stated.

Therefore, the international experience shows that there are minimum working conditions of domestic work issued by the ILO convention. The convention provides regulation, among others, regarding formation of contract, working hours, minimum age for employment, remuneration, safe and healthy working environment, freedom of association, condition of termination of employment contract and its effects. These standards provide special protection for domestic workers taking their vulnerability into consideration.

\subsection{The Experience of African Countries}

\subsubsection{Kenya}

A domestic worker is an employee like any other and the provisions of the labour laws apply equally to them and they are not excluded from the scope of application of the labour law (Employment Act, 2007). In Kenya, the 2010 Constitution and the Employment Act of 2007 guarantee every worker favorable working conditions and hence domestic workers should be accorded decent work. This involves enhancing their occupational safety and health; improving their standards of living; enhancing their social security; proper remuneration as well as ensuring that the rights and fundamental freedoms of the domestic workers are upheld and safeguarded.

The Employment Act provides the basic rights and fundamental freedoms of domestic workers (Employment Act, 2007). If a domestic worker is employed for three months or more, then the employer should draw up an employment contract (Employment Act, 2007). However, a verbal contract is also can confer rights and can be enforced. The contract should incorporate particulars of employment like the form and duration of contract, job description, remuneration, and all applicable benefits, leave entitlements, hours of work and the applicable termination notice period (Employment Act, 2007).

In addition to these, domestic worker are entitled varieties of privileges and leaves (Employment Act, 2007). Accordingly, they are entitled to fully paid annual leave not less than 21 days; sick leave not less than seven days on full pay and half paid seven days; maternity leave not less than 90 days; paternity leave not less than 14 days; weekly rest not less one day; overtime and remuneration not less than the prescribed minimum wage. Domestic workers have the right to form and join trade unions. It is also unlawful to employ a child who is under the age of 13 years and children between 13 and 16 years may be employed to do light work which do not harm the child's health or development or prejudice the child's attendance at school or participation in approved vocational training.

The employment act also provides termination procedures (Employment Act, 2007). For termination of employment contract, there must be a valid reason. 
The reasons for the termination must be clearly explained and a disciplinary hearing should be accorded where the employee can make representations on the allegations. Those reasons may relate to performance or conduct of the employee or the operational requirements of the employer and the burden of proving validity of the reason lies on the employer. The notice for termination should not be less than one month for monthly paid employee. In case of unlawful termination, the employee must be compensated up to 12 month's salary. According to the notice issued by the Cabinet Secretary, breach of the rules may lead to a jail term of 3 months or fine or both.

\subsubsection{Republic of South Africa (RSA)}

In South Africa, domestic workers are not excluded from labour law and treated similarly with any other worker. Domestic workers are governed by Labour Relations Act (LRA) and Basic Conditions of Employment Act (BCEA) which fills in the gaps of the LRA by creating a floor of employment rights (Tanzer, 2013). The former Act allows domestic workers to form and join trade unions, and to participate in the lawful activities of their unions or federations (Tanzer, 2013). This Act also provides that workers can engage in such protected labor activity without the employer imposing an adverse employment activity such as hiring discrimination or requiring that a worker cease his or union membership (Tanzer, 2013).

The latter Act also does not exclude domestic worker and the Unemployment Insurance Act (UIA) was amended to include domestic workers. It specifically provides regulation of hours, leave, remuneration, termination and also prohibits forced and child labour. Accordingly, the maximum weekly hours of work should not be more than 45 hours with one and one-half times pay for every hour of overtime. The act requires a 12 hours daily rest period and 36 hours weekly rest period but the daily rest period may be only 10 hours if the employee lives on the work premises and takes a meal interval lasting at least three hours. There are also various types of leave such as annual leave, sick leave, maternity leave, and family responsibility leave. For example, fully paid annual leave should not be less than 21 consecutive days.

There is also regulation as to minimum wage. The labour law system in South Africa recognizes the need for a safety net for workers in unrecognized sectors in the form of minimum wages and conditions of employment determined by the state (Social Law Project, 2014). The overtime payment is also recognized. However, overtime is voluntary and may only be worked by agreement between employer and employee. Besides these, all forms of forced labour are also totally prohibited.

\subsection{The Ethiopian Experience}

The current Labour Proclamation No. 1156/2019 of Ethiopia like the previous Labour Proclamation No. 377/2003 is excluded contracts of personal service from its scope of applicability (Labour Proclamation No. 1156 Article 3(2) (c), 2019). 
The Council of Ministers has also empowered to issue regulations governing conditions of work applicable for domestic workers (Labour Proclamation No. 1156 Article 3(3) (c), 2019). However, there is no regulation issued until today. Workers, other than domestic workers, are entrusted with special labour rights provided in the labour law (Labour Proclamation No. 1156, 2019). So, domestic workers are out of the scope of coverage of the labour law of Ethiopia and hence the conditions of work of domestic workers left unregulated by the labour law of the country. Nonetheless, the proclamation only provided definition for the term private service. The term "private service" is used instead of "domestic work" by the proclamation and defined as employment of a non-profit careening, cleaning guardianship, gardening, driving and other related services for the employer and his family consumption (Labour Proclamation No. 1156 Articles 3(2) (d) and 2 (16), 2019). Except this definitional provision, there is no regulation regulating domestic workers in the proclamation.

The regulation of condition of domestic worker may be covered by the general law. There are some provisions which regulate domestic workers under the Civil Code of Ethiopia (Civil Code Articles 2601-2604, 1960). Where the domestic worker lives with the employer's family, it is under employer discretion to supply living quarters, food, times of work and rest, take all reasonable steps to safeguard the health and moral well-being of the domestic worker (Civil Code Articles 2601-2603, 1960). The wages of such employees must be paid every three months, unless otherwise agreed (Civil Code Article 2604(1), 1960).

However, the code provides lower protection and benefits for domestic workers compared with that of the protection and benefits accorded to other groups of workers (Gebremedhin, 2016). If a domestic worker lives with the employer's family, the latter has an obligation to take reasonable measures regarding living-quarters, food, health, times of work and rest (Civil Code Articles 2601 and 2602(1), 1960). The duty of employer by way of medical attendance should be limited to one month where the illness occurs after at least one year from the beginning of the contract and to two weeks where it occurs after at least three months from the beginning of the contract (Civil Code Article 2602(2), 1960). The employer can set off expenses which he incurs against the wages of the domestic worker (Civil Code Article 2602(3), 1960). The employer may not be relieved from this obligation by terminating the contract on the ground of the illness of the domestic worker (Civil Code Article 2603(3), 1960). But he may be relieved from these obligations when the illness has been intentionally contracted by the domestic worker or the latter goes into hospital under a scheme of compulsory insurance (Civil Code Article 2603(1) and (2), 1960).

Regarding the payment of wages, unless otherwise agreed, wages of domestic worker living with the employer must be paid every three months (Civil Code Article 2604(1), 1960). The wages should in any case be paid where the contract terminates (Civil Code Article 2604(2), 1960). Hence, the legal protection provided for domestic workers under the civil code is not adequate and failed to take their special vulnerability into consideration. 


\section{Some of the Challenges on the Protection of Domestic Workers in the Study Area}

There are some findings obtained through analysis and interpretation of data collected by using questionnaires, interviews and focus group discussions in the study area. According to the questionnaires and interview collected from domestic workers and employers, almost all domestic workers in the town are migrant workers from the rural areas (Interview made with Tadelech Amare). The questionnaires and interviews were conducted with domestic workers and employers who have more than three years' experience and exposure on domestic work. The causes of domestic work are family problems, poverty, high number of children in the family and illiteracy.

The common types of domestic works practiced in the study area include cleaning room, fetching water, washing clothes, and carrying goods, baking and etc. Domestic workers have no written agreement with their employer concerning to their rights, duties and conditions of work particularly regarding hours of work, scope of duty, amount of wage, leave, duration, working environment, termination and other conditions of work. The vast majority of the domestic workers live with the employers. Those domestic workers who live with the employers are not given adequate food and clean living room, there is no limited hour of work and they are obliged to do work at any time without rest including during night time. The interview made with domestic workers shows that they are not provided with adequate food, working environment is not safe and healthy (Interview made with Alemitu Dana). According to questionnaires collected from domestic workers, in the majority of cases, there is no expressly agreed amount of wage and they work without any wage or with very low wage. However, some of the domestic workers confirmed that they are paid though the amount is insignificant (Interview made with Aynalem Ayano).

Domestic workers are specially exposed to various types of abuses including sexual violence as the vast majority of them are female and children (Interview made with Kirubel Getachew). The questionnaires collected also shows that domestic workers are not organized to struggle for the protection of their rights. The discretion either to maintain or terminate the employment contract is on the hand of the employer because of bargaining power imbalance. If the employer wishes, he/she can terminate the contract at any time without any compensation or even without paying wage. Furthermore, domestic workers and their employers have no awareness regarding the types and scope of their rights and duties. The summary of the responses collected from the focus group discussion with the concerned government officers also support the above facts.

\section{Conclusion}

This research work attempts to explore legal protection for domestic workers, who are extremely vulnerable, facing with varieties of abuses and violence in the study area. The finding revealed that the rights and interests of domestic workers 
are not protected because of bargaining power imbalance, lack of clear employment contract, illiteracy and working in private household, lack of awareness and weak realization of laws and failures of the organs of government. Due to their vulnerability, domestic workers need special legal protection.

Internationally, the ILO has enacted Domestic Workers Convention No. 189 in the year 2011 and Recommendation No. 201 taking their special vulnerability into consideration. Accordingly, special labour rights and privileges are issued to protect domestic workers. Some countries of the world adopted the convention as part of their domestic law. On the other hand, some African countries such as Kenya and South Africa treat domestic workers in a similar manner with any other workers. In other words, labour laws of these countries also apply to domestic workers.

In Ethiopia, however, labour law has excluded domestic workers from labour law protection. The current labour proclamation of Ethiopia has expressly excluded domestic workers from its scope of application. In addition to this, the worst thing is that there is no other special law enacted to protect the rights and privileges of domestic workers taking their special vulnerability into account. The protection provided under the Civil Code of 1960 is not adequate and fails to recognize special vulnerability of domestic workers in to consideration.

The Ethiopian government should either extend the applicability of the labour law for domestic workers or enact other special law which specifically governs domestic workers. Domestic workers need special protection due to their special vulnerability. Ethiopia, as a member state of the ILO and UN, also needs to ratify the ILO Convention for domestic workers by the law making organ (i.e. House of Peoples Representatives). Besides these, the Council of Ministers should also issue the regulation governing conditions of work applicable for domestic workers pursuant to article 3(3)(c) of the Labour Proclamation No. 1156/2019. Domestic workers need special legal protection, among others, regarding hours of work, overtime payment, leave, minimum wage, health care, human dignity and sexual harassment, termination of employment, social security protection and action against child domestic work. The law should provide minimum working conditions to protect domestic workers against abuses and violations of the rights.

In addition to enactment of law, awareness creation must be conducted by the concerned organs (i.e. governmental and non-governmental organizations) for domestic workers and employers. Both domestic workers and their employers need awareness creation concerning their respective rights and obligations. Furthermore, domestic workers should form association and organized to strengthen their bargaining power in order to struggle for their rights and privileges.

\section{Conflicts of Interest}

The authors declare no conflicts of interest regarding the publication of this paper. 


\section{References}

Asia Pacific Forum on Women, Law and Development, 2010, the Right to Unite, a Handbook on Domestic Worker Rights across Asia.

Azzam, O. F. (2019). An Introduction to Labour Law. Helwan: Helwan University, Faculty of Law. http://www.researchgate.net/publication

Berlanstein, L. R. (1992). The Industrial Revolution and Work in Nineteenth Century Europe (pp. 134-152). London: Routledge.

Civil Code of the Empire of Ethiopia Proclamation No. 165/1960, Negarit Gazette, Extra-Ordinary Issue No. 2, Addis Ababa, Ethiopia, 11 September, 1960.

Employment Act, 2007, Republic of Kenya Gazette Supplement Acts No. 107 (Acts No. 11), 26th October, Nairobi, Kenya.

Federal Democratic Republic of Ethiopia (FDRE) Constitution Proclamation No. 1/1995, Federal Negarit Gazette, 1st year No. 1, Addis Ababa, Ethiopia, 21st August, 1995.

Gebremedhin, M. M. (2016). Procrastination in Recognizing the Rights of Domestic Workers in Ethiopia. Mizan Law Review, 10, 38-72. https://doi.org/10.4314/mlr.v10i1.2

Human Rights Watch (2012). The ILO Domestic Workers Convention: New Standards to Fight Discrimination, Exploitation and Abuse.

Human Rights Watch (2018). Domestic Workers Rights in Qatar: Human Rights Watch Commentary on Qatar's Laws and Regulations on Domestic Workers.

ILO (2013). Domestic Workers across the World: Global and Regional Statistics and the Extent of Legal Protection. Geneva: ILO Publication.

ILO Convention (2011). Social Protection Sector. Geneva: ILO Publication.

ILO Convention on Decent Work for Domestic Workers No. 189, 2011. Geneva: ILO Publication. http://www.ilo.org/travail

ILO International Labour Organization (2012). Effective Protection for Domestic Workers: A Guide to Designing Labour Laws. Geneva.

International Trade Union Confederation (2010). Action Guide: Decent Work, Decent Life for Domestic Workers. Brussels.

Interview with Alemitu Dana, Interview Conducted on April 05, 2020.

Interview with Aynalem Ayano, Interview Conducted on April 13, 2020.

Interview with Mr. Kirubel Getachew, Officer in Wolaita Sodo Town Female and Children, Interview Conducted on April 07, 2020.

Interview with Tadelech Amare, Interview Conducted on April 10, 2020.

Labour Proclamation No. 1156/2019, Federal Negarit Gazette, 25th Year No. 89, Addis Ababa, Ethiopia, 5 September 2019.

Mulugeta, K. (2012). Vulnerability, Legal Protection and Work Conditions of Domestic Workers in Addis Ababa. The Hague: International Institute of Social Studies.

Redae, M. (2009). Employment and Labour Law. Addis Ababa: Justice and Legal System Research Institute.

Social Law Project (2014). Domestic Workers' Law and Legal Issues in South Africa. WIEGO Law and Informality Resources. Cambridge, MA: WIEGO.

Tanzer, Z. (2013). Domestic Workers and Socio-Economic Rights: A South African Case Study. Washington DC: Solidarity Center. 